\title{
REVIEW
}

\section{Pharmacy education in Indonesia}

\author{
Fonny Cokro ${ }^{1}$ iD , Pretty Falena Kambira Atmanda ${ }^{1}$ iD, Reynelda Juliani Sagala ${ }^{1}$ iD,

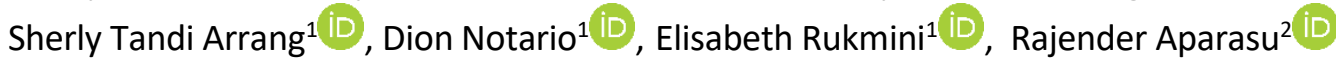 \\ ${ }^{1}$ School of Medicine and Health Sciences, Atma Jaya Catholic University of Indonesia, Jakarta, Indonesia \\ ${ }^{2}$ College of Pharmacy, University of Houston, Houston, Texas, United States
}

Keywords
Education
Indonesia
Pharmacy
Professional
Undergraduate
Correspondence
Rajender Aparasu
College of Pharmacy
University of Houston
Houston
Texas
United States
rraparasu@uh.edu

\section{Keywords}

Professional

Correspondence

Rajender Aparasu

College of Pharmacy

University of Houston

Texas

rraparasu@uh.edu

\begin{abstract}
Pharmacy education in Indonesia mainly involves a four-year undergraduate degree, followed by a one-year professional pharmacy programme. The curriculum and learning outcomes of undergraduate and professional pharmacy programmes follow academic standards set by the Association of Indonesian Pharmacy Higher Education, based on the Seven Star Pharmacist concept developed by the World Health Organisation (WHO). Most pharmacy undergraduate programmes are focused on general pharmacy skills and knowledge, which includes pharmaceutical sciences and clinical pharmacy. Professional pharmacy programmes provide more pharmacy practice training and skills; thus, graduates have broader career opportunities than undergraduates because they are prepared for higher responsibilities within pharmacy practice. Although there have been significant improvements in pharmacy education, there remain challenges related to government policies, stakeholder agreements, educational offerings, competencies, and training. This requires considerable collective efforts from the government, educational systems, associations, and other stakeholders to improve the role of pharmacists in Indonesia.
\end{abstract}

\section{Introduction}

Indonesia is one of the developing countries in Asia, with a population of 261 million spread over 17,508 islands (Embassy of the Republic of Indonesia Washington DC, 2017; World Health Organisation, 2020). It is the fourth largest populated country in the world with numerous islands. Most of the population live on Java Island, and the capital city Jakarta, is also located on this island. The Indonesian educational universities are also mostly found on Java Island (Indonesian Ministry of Education and Culture, 2020). The education delivery systems are mostly located in populated cities. $16 \%$ of young adults have completed tertiary education (Organisation for Economic CoOperation and Development (OECD), 2019). Indonesia is ethnically diverse, with approximately 1,300 ethnic groups and 2,500 languages and dialects. Most Indonesians speak the national language of Bahasa (Central Bureau of Statistics, 2010).
Population health measures have improved significantly in the past two decades as evidenced by increasing life expectancy (63 years in 1990 to 71 years in 2012) and decreasing mortality rates of under five year olds (52 deaths per 1000 live births in 2000 to 31 deaths in 2012) (Mahendradhata et al., 2017). This is attributed to improvements in health systems involving public and private sectors and healthcare financing. Central and provincial health ministries are engaged in public health systems. Also, there are private hospitals and systems supported by for-profit and non-profit organisations. Healthcare expenditures have significantly increased; however, it only accounts for about 3\% of gross domestic product (Mahendradhata et al., 2017). The central government has recently implemented the national health insurance system - Jaminan Kesehatan Nasional (JKN) to control healthcare costs. The JKN is funded by contributions from individuals and the government (Mahendradhata et al., 2017). 
The increase in healthcare needs, combined with national health insurance implementation, has resulted in significant improvements in the healthcare infrastructure, including health systems, hospitals, clinics, and providers. Consequently, the need for healthcare professionals has also significantly increased. However, the physician to population ratio is still lower than recommended by the World Health Organisation (WHO), which is one physician per 10,000 people (World Health Organisation, 2014; Asia Pacific Observatory on Health Systems and Policies, 2017). The need for other healthcare professionals such as pharmacists also increased, aligned with enhancing the role and responsibilities of pharmacists (Mahendradhata et al., 2017; Hermansyah et al., 2018). Therefore, pharmacy schools are also growing in order to serve the training needs. There are currently 230 pharmacy undergraduate programmes (Indonesian Ministry of Education and Culture, 2020). Additionally, there is significant interest from prospective pharmacy education students (Media, 2021).

This article discusses the current pharmacy education system and explores the possible solutions to increase the quality of pharmacy education in the country. Although similar articles are available on pharmacy education literature for a few Asian countries such as Vietnam and Thailand (Vo et al., 2013; Chanakit et al., 2014), no information is available for Indonesia. Therefore, this article will serve as an important step in filling the literature gap regarding pharmacy education in Indonesia with respect to educational programmes, learning outcomes, curriculum, admission process, career opportunities, and challenges.

\section{Pharmacy educational programmes in Indonesia}

The pharmacy educational programmes in Indonesia start after high school. There are two options: a three-year vocational school or a fouryear undergraduate degree. The vocational school programme includes essential knowledge and pharmacy skills, including pharmaceutical care, pharmacognosy, pharmacology, and pharmaceutical chemistry. This programme is a six-semester programme that provides up to 120 credits. After graduating from the vocational programme, the student may continue to the undergraduate programme after credit assessment in the admission process (Health Ministerial Regulation on Registration, Practice License, and Work Permit for Pharmaceutical Personnel, 2011; Amendment to Health Minister Regulation Number 889/MENKES/PER/V/2011 concerning Registration, Practice License, and Work Permit for
Pharmaceutical Personnel, 2016; Andayani \& Satibi, 2016). Others may work as pharmacist assistants in various health care providers or pharmaceutical industries, with limited roles and responsibilities.

The undergraduate pharmacy programme is a fouryear programme, and the graduate earns a Bachelor of Pharmacy (B. Pharm) degree. The programme requires at least 144 credits in eight semesters as per the Association of Indonesian Pharmacy Higher Education (2013). Afterwards, a graduate may choose to pursue either a professional pharmacy programme or a master's degree programme. A professional pharmacy programme is a one-year professional preregistration programme prior to being qualified as a pharmacist. This programme is a training programme that consists of at least 36 credits for two semesters (Association of Indonesian Pharmacy Higher Education, 2013; Andayani \& Satibi, 2016). Meanwhile, a Master of Science programme is a two-year programme to earn a Master's degree. This programme has two focus domains: pharmaceutical science and clinical pharmacy. After completing the Master's degree, students are eligible to continue for a doctoral (Ph.D.) programme specialising in the student's research interests.

Moreover, a special programme called 'Doktor Unggulan' by the Institute of Technology Bandung (ITB) allows a graduate to directly pursue a doctoral programme within three years without the need for a Master's degree. However, the selection, monitoring, and evaluation processes are rigorous in order to ensure students can finish the programme within the allocated time (School of Pharmacy ITB, 2021). Compared to other Southeast Asian countries, Vietnam also has a similar pharmacy education programme (Vo et al., 2013). However, instead of the professional pharmacy programme, they have two diploma programmes, the first and second level of specialisation in pharmacy programme; First-Level Diploma of Specialisation In Pharmacy (FDSPharm) and Secondary Diploma in Pharmacy (SDSPharm) (Vo et al., 2013). Meanwhile, in India, there are three levels of pharmacy programmes available: diploma, undergraduate, and a Master's degree. In recent years, a six-year Doctor of Pharmacy (Pharm.D.) programme encompassing a one-year internship programme focusing more on clinical and community profession was also introduced (Basak \& Sathyanarayana, 2010). Thailand had a five-year Bachelor of Pharmacy (B.Pharm.) programme in the majority before 2010. It consisted of a number of different tracks, including pharmaceutical technology, pharmaceutical care, and social 
pharmacy. In 2008, the Pharmacy Council of Thailand mandated a six-year Pharm.D. programme throughout the country. Therefore, the B.Pharm. programme was not offered after 2010. A Pharm.D. degree in Thailand now requires a minimum of 140 credit hours of professional content to be fulfilled. The first four years of the system provide core competencies for professional practice. The next two years of Pharm.D. are selected or specialised fields that students are able to choose. In the fifth year, students have to undertake coursework, and in the sixth year, they undertake clerkships. This system is relatively similar to pharmacy education in the United States (USA). In six years of study, a Pharm.D. student in Thailand has to dedicate $51.5 \%$ of their time to theory, $46.7 \%$ to practice, and $1.8 \%$ to research (Chanakit et al., 2014).

\section{Competencies of pharmacy graduates}

The competency differences between graduates of the undergraduate and professional pharmacy programme are reflected in the curriculum content of the programmes. The Indonesian competency standards for undergraduates and professional pharmacy graduates consists of eight competencies: 1) competency of safe optimisation of drug use; 2) competency of drug dosage services; 3) competency of drug dosage production and distribution; 4) competency of drug and information services; 5) competency of interpersonal communication and collaboration; 6) competency of leadership and management; 7) competency of professional practices both legal and ethical; and 8) competency of mastery of knowledge, research ability, and personal development (Association of Indonesian Pharmacy Higher Education, 2013). In contrast, the competencies of vocational programme are: 1) the competency of drug dosage services; 2) competency of drug dosage production and distribution; and 3) competency of mastery of knowledge, research ability, and personal development (Indonesian Ministry of Health, 2016).

Competencies of pharmacy graduates are intended to reflect the roles of pharmacists based on the "Seven-star Pharmacist" developed by the WHO and the International Pharmaceutical Federation (FIP) standards (Wiedenmayer et al., 2006). The seven-star pharmacist requires the pharmacist to be qualified for various roles; caregiver, decisionmaker, communicator, leader, manager, life-long learner, and teacher (World Health Organisation, 1997; Azhar et al., 2009). Therefore, the curriculum and learning outcomes must accommodate students to achieve these competencies. In Indonesia, Association of Indonesian Pharmacy
Higher Education (Asosiasi Pendidikan Tinggi Farmasi Indonesia-APTFI) developed and added three additional competencies: personal/professional responsibilities, scientific comprehension, and research abilities (Association of Indonesian Pharmacy Higher Education, 2013). In contrast, competencies in Master's and Doctoral programmes emphasise students' profession and research interest based on each institution's vision. The Indonesian Qualification Framework (Kerangka Kualifikasi Nasional Indonesia - KKNI) is used as the standard for competency in these graduate levels, which is level eight for a master programme and level nine for a doctoral programme (Regulation of the President, the Republic of Indonesia No. 8, 2012).

There are some differences related to undergraduate and professional graduates' achievements despite them having similar learning outcomes (Association of Indonesian Pharmacy Higher Education, 2013). For the learning outcome of a caregiver, both graduates of a Bachelor of Pharmacy programme and professional pharmacy programme are expected to have the capability of identifying patients' drug-related problems and find the solutions regarding those problems; however, in the professional pharmacy programme, the emphasis is on solving the drug-related problems. In the industrial setting, a professional pharmacist is expected to be able to design, develop, and produce safe, effective, stable, and quality pharmaceutical products. Moreover, a professional pharmacist is expected to be able to manage the supply and distribution of pharmaceutical preparations and medical devices. This requires a comprehensive understanding of the professional pharmacist's skills, such as scientific comprehension and research abilities. Furthermore, a graduate with a Bachelor of Pharmacy degree who works in pharmaceutical marketing or sales is expected to be able to evaluate and synthesise drug information; meanwhile, a professional pharmacist is expected to be able to provide drug information and education accurately. Finally, a professional pharmacist is expected to achieve seven-star pharmacist characteristics such as life-long learner, manager, decision-maker, communicator and personal/professional responsibilities (Association of Indonesian Pharmacy Higher Education, 2013).

A professional pharmacy programme is an advanced degree for those who have completed an undergraduate in pharmacy education. This programme consists of several mandatory internships or field training, which represents at least $60 \%$ of the total programme. This training is carried out in clinical, community, and industrial 
settings. During the training, students learn and practise in real-time pharmacy settings. Moreover, $70-80 \%$ of the curriculum's core is composed of case studies, practice, and internships (Association of Indonesian Pharmacy Higher Education, 2013).

The spread of undergraduate and professional pharmacist schools in Indonesia based on the Ministry of Research, Technology and Higher Education of Indonesia is shown in Figure 1. The data were accessed in 2019. Most of the pharmacy schools (both undergraduate and professional) are located on Java Island. Moreover, there are only four professional pharmacy schools in Indonesia's eastern part, none in Papua, Nusa Tenggara, or any other island outside Sulawesi and Bali (Indonesian Ministry of Education and Culture, 2020). Therefore, students from east Indonesia come to the western part of the country to pursue their professional pharmacy education. Consequently, it is challenging for students to get a professional degree because of limited access to pharmacy programmes as there are only 43 professional pharmacy programmes compared to 230 pharmacy undergraduate programmes.

\section{a. Pharmacy undergraduate schools in Indonesia}

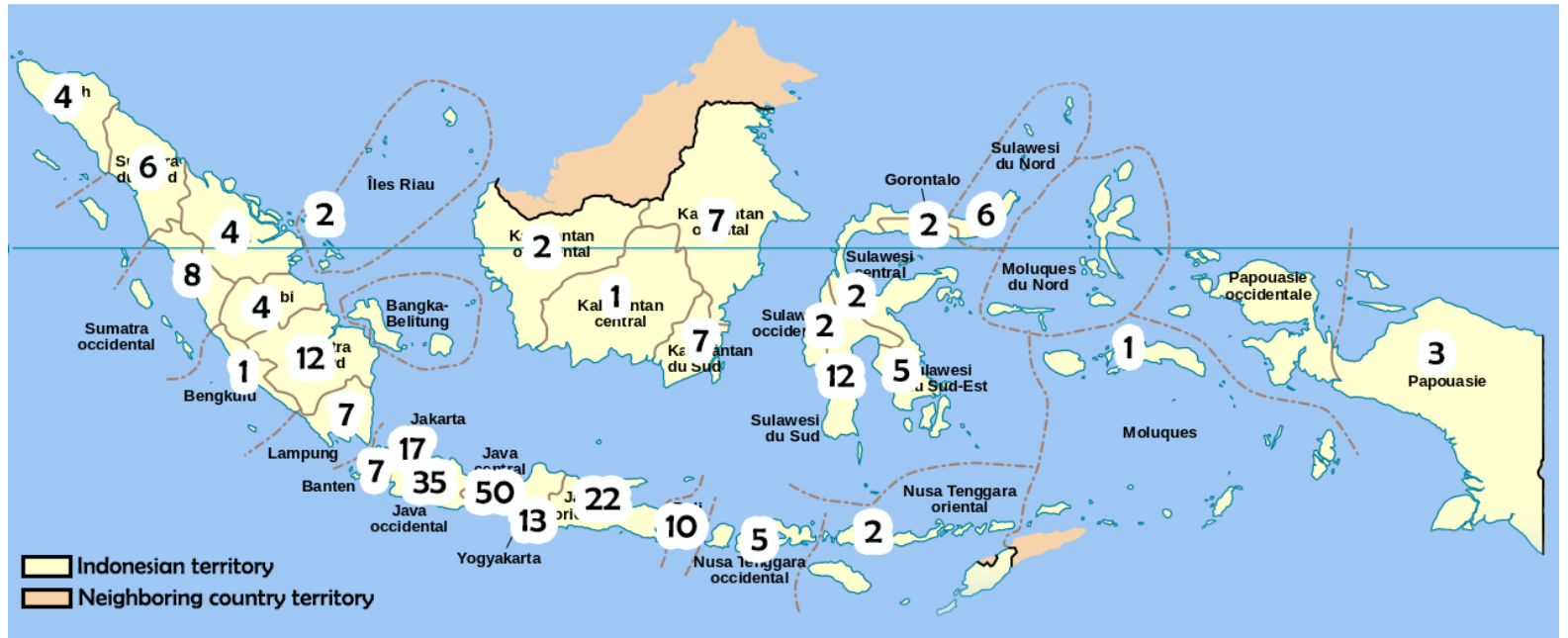

b. Professional pharmacy school in Indonesia

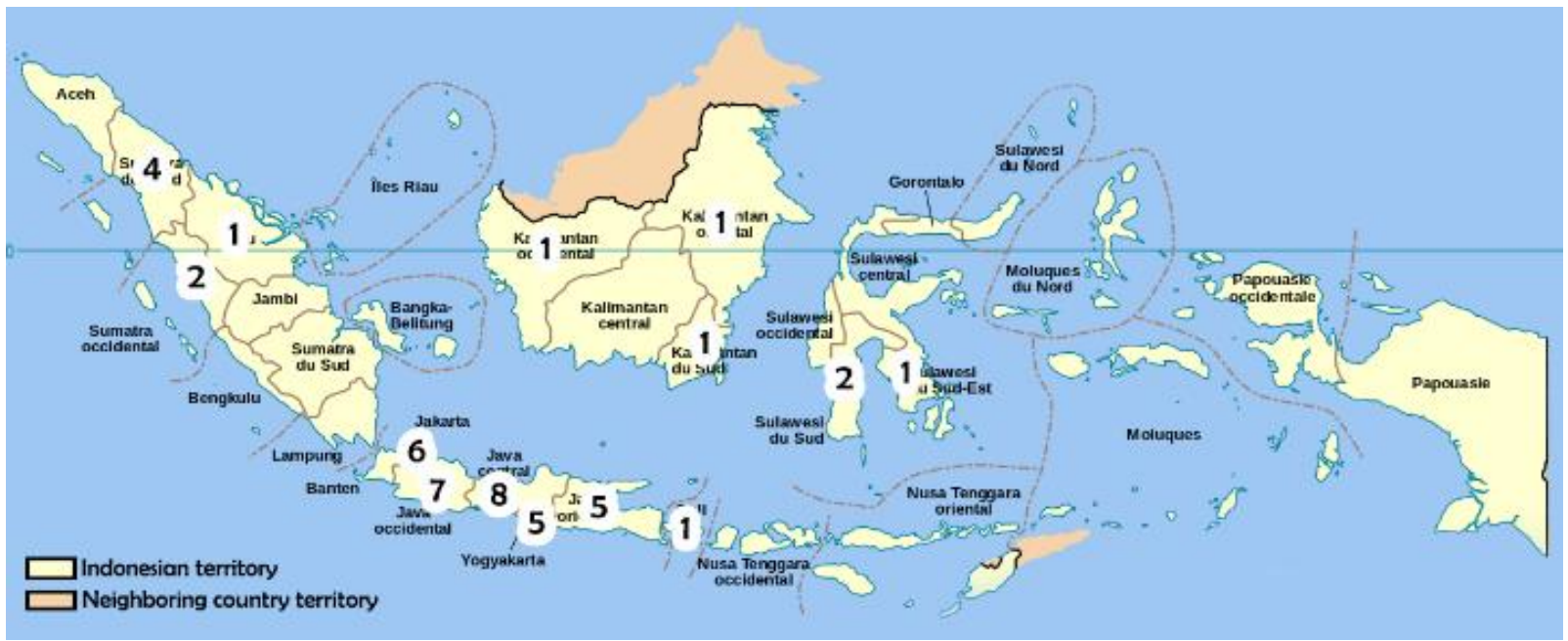

Adapted from Wikimedia under the terms of the GNU Free Documentation License; Numbers in the picture indicate the number of schools in each province.

Figure 1: Number of pharmacy schools in Indonesia

If a school has both undergraduate and professional programmes, students can advance directly to the professional programme. Otherwise, the graduates have to apply to different schools to pursue their professional degrees. The admission requirements for the professional programme generally include grade point average, a test of English as a foreign language, potential academic tests, and the programme's accreditation status (Brawijaya University, 2020; University of Indonesia, 2021).

\section{Pharmacy curriculum in Indonesia}


The national curriculum or competency standards for vocational and undergraduate programmes are designed by the Association of Indonesian Diploma Education (APDFI) and APTFI, respectively. (Association of Indonesian Pharmacy Higher Education, 2013; Indonesian Ministry of Health, 2016). The study materials, processes, and assessments in the programme curriculum are set as per the APDFI and APTFI. The pharmacy education curriculum in Indonesia consists of a) a mandatory curriculum (general), b) a core curriculum pharmacy, and c) a local curriculum. The content of the mandatory and core curricula are set by the APTFI and APDFI. On the other hand, the local curriculum content is adapted from the vision and mission of each pharmacy educational institution (Association of Indonesian Pharmacy Higher Education, 2013). All students must take the mandatory and core curricula, while some courses in the local curriculum can be mandatory, and others are considered electives. The elective curriculum allows students to develop their respective special interests (Association of Indonesian Pharmacy Higher Education, 2013; Indonesian Ministry of Health, 2016). The curricula for the pharmacy undergraduate and professional pharmacy programme are provided in Table I (Association of Indonesian Pharmacy Higher Education, 2013).

The pharmacy undergraduate education programme focuses on mastering knowledge and skills (knows \& know-how) in the field of pharmacy. The mastery of science includes basic biomedical sciences, pharmaceutical sciences, statutory provisions, leadership, management, and self-development (soft skills). The curriculum content of the professional pharmacy programme is more focused on mastering the skills and ability to practise professionally (show-how) in clinical pharmacy, community pharmacy, and industrial pharmacy (as detailed in Table II).

The method of knowledge delivery in the pharmacy undergraduate programmes is focused on lecture activities and/or practice in the laboratory (Association of Indonesian Pharmacy Higher Education, 2013). The curriculum of professional pharmacy programme involves case studies, problem-solving, assignments/projects, and professional work practice in professional practice facilities with the guidance of practitioners as a preceptor. The proportion of professional work in the workplace facilities is at least $60 \%$ of the total curriculum content (Association of Indonesian Pharmacy Higher Education, 2013). Regarding the Master of Pharmacy and Doctoral programme, there are no specific standards that must be followed.
Table I: Curriculum framework of pharmacy programmes in Indonesia

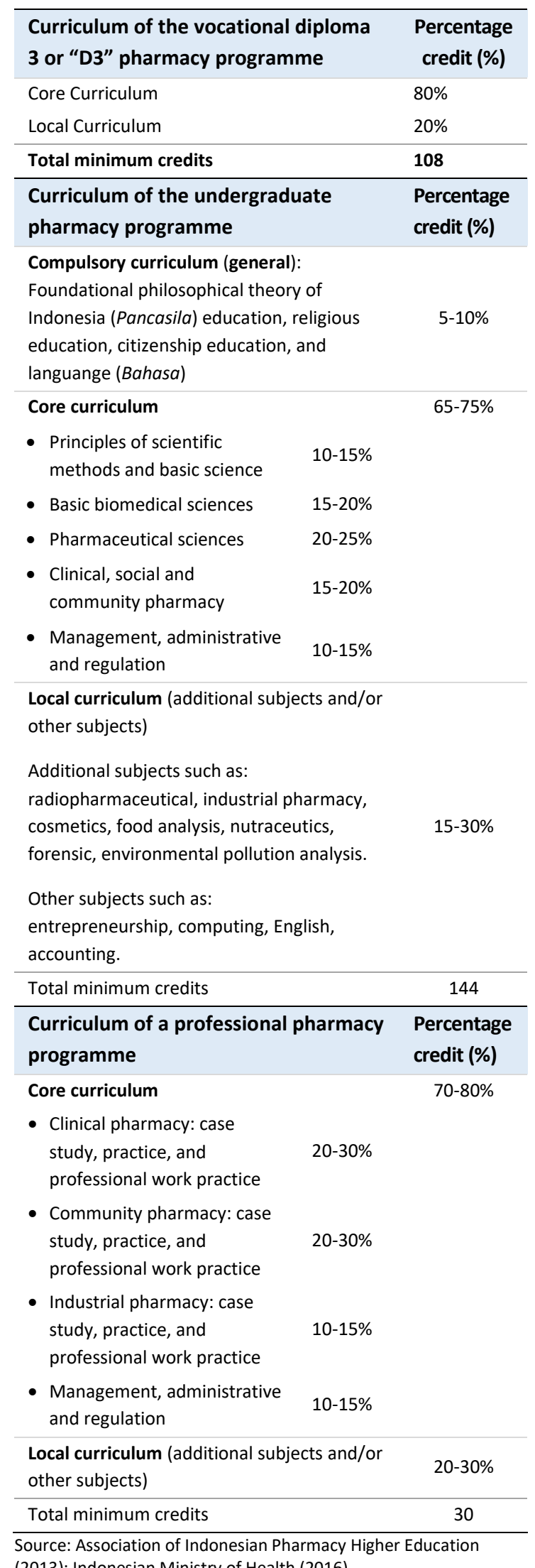

(2013); Indonesian Ministry of Health (2016) 
Table II: Pharmacy competency standards of pharmacy programmes in Indonesia

\begin{tabular}{|c|c|c|c|}
\hline \multirow{2}{*}{$\begin{array}{l}\text { Competency } \\
\text { of pharmacy }\end{array}$} & \multicolumn{3}{|c|}{ Standards of ability } \\
\hline & $\begin{array}{l}\text { Vocational pharmacy } \\
\text { programme (Diploma) }\end{array}$ & $\begin{array}{c}\text { Undergraduate pharmacy } \\
\text { programme (Bachelor) }\end{array}$ & $\begin{array}{c}\text { Professional pharmacy } \\
\text { programme (pre-registration) }\end{array}$ \\
\hline $\begin{array}{l}\text { Safe } \\
\text { optimisation of } \\
\text { drug use }\end{array}$ & & $\begin{array}{l}\text { 1. Explaining considerations during drug } \\
\text { selection } \\
\text { 2. Analysing appropriateness of } \\
\text { therapeutic drug design } \\
\text { 3. Identifying drug-related problems and } \\
\text { alternative solutions }\end{array}$ & $\begin{array}{l}\text { 1. Participating actively in the } \\
\text { selection of drug therapy } \\
\text { 2. Monitoring and evaluating patient } \\
\text { treatment } \\
\text { 3. Monitoring and evaluating adverse } \\
\text { drug reactions } \\
\text { 4. Evaluating drug usage } \\
\text { 5. Monitoring drug levels in the blood }\end{array}$ \\
\hline $\begin{array}{l}\text { Drug dosage } \\
\text { services }\end{array}$ & $\begin{array}{l}\text { 1. Executing prescription services } \\
\text { (receipt, screening, administration, } \\
\text { preparation and compounding, and } \\
\text { counselling) } \\
\text { 2. Conducting self-medication service } \\
\text { 3. Managing pharmacy dosage, } \\
\text { medical equipment, consumable } \\
\text { medical materials } \\
\text { 4. Conducting clinical pharmacy } \\
\text { technical work based on applicable } \\
\text { ethical and legal aspects }\end{array}$ & $\begin{array}{l}\text { 1. Conducting prescription screening } \\
\text { 2. Explaining the option of drug therapy } \\
\text { in self-medication service } \\
\text { 3. Preparing non-sterile drug dosage } \\
\text { 4. Dispensing sterile dosage } \\
\text { 5. Ensuring drug's quality assurance } \\
\text { 6. Delivering pharmaceutical dosage to } \\
\text { patients }\end{array}$ & $\begin{array}{l}\text { 1. Conducting prescription validation } \\
\text { 2. Evaluating options for drug therapy } \\
\text { in prescription } \\
\text { 3. Providing recommendations on the } \\
\text { option of pharmacy dosage self- } \\
\text { medication service } \\
\text { 4. Preparing non-sterile pharmacy } \\
\text { dosage } \\
\text { 5. Handling dispensing of injection } \\
\text { dosage } \\
\text { 6. Handling medical equipment } \\
\text { sterilisation } \\
\text { 7. Handling cytotoxic drugs } \\
\text { 8. Ensuring pharmacy dosage quality } \\
\text { 9. Delivering pharmacy dosage to } \\
\text { patients }\end{array}$ \\
\hline $\begin{array}{l}\text { Drug dosage } \\
\text { production and } \\
\text { distribution }\end{array}$ & $\begin{array}{l}\text { 1. Mastering the basic concept, } \\
\text { principle of theory and practise as } \\
\text { well as conducting production work } \\
\text { of pharmacy dosage which includes } \\
\text { measuring, dispensing, printing, } \\
\text { packaging, and storing in } \\
\text { accordance with good drug } \\
\text { manufacturing practices under the } \\
\text { prevailing legal aspect } \\
\text { 2. Conducting distribution of pharmacy } \\
\text { dosage, medical equipment, vaccine } \\
\text { and medical consumables materials } \\
\text { referring to the good distribution } \\
\text { method under the applicable ethical } \\
\text { and legal aspects }\end{array}$ & $\begin{array}{l}\text { 1. Designing pharmaceutical formulation } \\
\text { 2. Considering the requirement of drug } \\
\text { dosage production } \\
\text { 3. Producing drug dosage in accordance } \\
\text { with quality assurance principles } \\
\text { 4. Evaluating drug dosage quality } \\
\text { 5. Distributing drug with quality } \\
\text { assurance principles }\end{array}$ & $\begin{array}{l}\text { 1. Establishing formulations and } \\
\text { procedures for pharmacy dosage } \\
\text { preparation } \\
\text { 2. Determining quality standards for } \\
\text { pharmacy dosage } \\
\text { 3. Managing manufacturing and } \\
\text { quality assurance of pharmacy } \\
\text { dosage } \\
\text { 4. Managing distribution and quality } \\
\text { assurance of pharmacy dosage }\end{array}$ \\
\hline $\begin{array}{l}\text { Drug and } \\
\text { information } \\
\text { services }\end{array}$ & & $\begin{array}{l}\text { 1. Evaluating and providing drug } \\
\text { information } \\
\text { 2. Providing information on drug and } \\
\text { medication } \\
\text { 3. Promoting rational drug usage }\end{array}$ & $\begin{array}{l}\text { 1. Exploring, analysing, synthesising, } \\
\text { and preparing drug information } \\
\text { 2. Managing information, } \\
\text { consultation, education services on } \\
\text { drugs or medication } \\
\text { 3. Managing promotion of rational } \\
\text { drug usage }\end{array}$ \\
\hline $\begin{array}{l}\text { Interpersonal } \\
\text { communication } \\
\text { and } \\
\text { collaboration }\end{array}$ & & $\begin{array}{l}\text { 1. Applying effective communication } \\
\text { principles } \\
\text { 2. Working with a team }\end{array}$ & $\begin{array}{l}\text { 1. Developing effective } \\
\text { communication with patients or } \\
\text { health workers } \\
\text { 2. Managing conflicts and developing } \\
\text { teamwork skills } \\
\text { 3. Developing inter-professional } \\
\text { collaboration with health workers }\end{array}$ \\
\hline
\end{tabular}




\begin{tabular}{|c|c|c|c|}
\hline \multirow{2}{*}{$\begin{array}{l}\text { Competency } \\
\text { of pharmacy }\end{array}$} & \multicolumn{3}{|c|}{ Standards of ability } \\
\hline & $\begin{array}{l}\text { Vocational pharmacy } \\
\text { programme (Diploma) }\end{array}$ & $\begin{array}{c}\text { Undergraduate pharmacy } \\
\text { programme (Bachelor) }\end{array}$ & $\begin{array}{c}\text { Professional pharmacy } \\
\text { programme (pre-registration) }\end{array}$ \\
\hline $\begin{array}{l}\text { Leadership and } \\
\text { management }\end{array}$ & & $\begin{array}{l}\text { 1. Managing independent and/or group } \\
\text { assignments } \\
\text { 2. Taking decisions based on information } \\
\text { or data } \\
\text { 3. Taking responsibility for independent } \\
\text { or group assignments }\end{array}$ & $\begin{array}{l}\text { 1. Managing independent or group } \\
\text { assignments } \\
\text { 2. Taking decisions based on } \\
\text { information or data analysis } \\
\text { 3. Taking responsibility for } \\
\text { independent or group assignments }\end{array}$ \\
\hline $\begin{array}{l}\text { Professional } \\
\text { practices, legal } \\
\text { and ethical }\end{array}$ & & $\begin{array}{l}\text { 1. Explaining about law and regulations } \\
\text { and ethical principles of pharmacy } \\
\text { 2. Complying with law and regulations, } \\
\text { norms and ethical principles of } \\
\text { pharmacy }\end{array}$ & $\begin{array}{l}\text { 1. Conducting pharmaceutical } \\
\text { practices in a professional, legal } \\
\text { and ethical manner } \\
\text { 2. Showing responsibilities in social } \\
\text { life }\end{array}$ \\
\hline $\begin{array}{l}\text { Mastery of } \\
\text { knowledge, } \\
\text { research } \\
\text { ability, and } \\
\text { personal } \\
\text { development }\end{array}$ & $\begin{array}{l}\text { 1. Mastering the concept of research } \\
\text { methodology, conducting data } \\
\text { collection, data processing and } \\
\text { drafting case reports and/or work } \\
\text { reports in accordance with health } \\
\text { and/or pharmacy research scope } \\
\text { based on the prevailing legal aspect. }\end{array}$ & $\begin{array}{l}\text { 1. Explaining the concept of medicine, } \\
\text { the human body, and the mechanisms } \\
\text { of drug action } \\
\text { 2. Explaining the relationship between } \\
\text { the structure of active ingredient } \\
\text { compounds with their activities } \\
\text { 3. Explaining the concept of drug } \\
\text { development from natural or synthetic } \\
\text { ingredients } \\
\text { 4. Explaining the concept of drug } \\
\text { pharmacokinetics } \\
\text { 5. Conducting physical, chemical, } \\
\text { physico-chemical, and biological } \\
\text { analysis of active ingredients or drug } \\
\text { products } \\
\text { 6. Applying science and technology in } \\
\text { pharmaceutical research } \\
\text { 7. Increasing knowledge and lifelong } \\
\text { learning for self-ability }\end{array}$ & $\begin{array}{l}\text { 1. Increasing knowledge and lifelong } \\
\text { learning for self-ability } \\
\text { 2. Conducting pharmaceutical } \\
\text { research for increasing therapeutic } \\
\text { success } \\
\text { 3. Improving the ability of } \\
\text { professional practise continuously }\end{array}$ \\
\hline
\end{tabular}

\section{Admission process in pharmacy programmes}

The admission process for the undergraduate pharmacy programme in Indonesia varies based on the type of university: public (government/state) or private. The government primarily regulates the admission process in public universities. Meanwhile, the private university's admission process is selfregulated; therefore, the process is more modest than the state universities. Consequently, each private university will have a unique admission system, criteria, and schedule. Generally, the administrative requirements are a senior high school certificate specialising in science, good health conditions with no partial or total colour blindness (Brawijaya University, 2019; Atma Jaya Catholic University of Indonesia, 2021; College Entrance Test Institute, 2021). The application process requires prospective students to apply and qualify through an entrance examination, which consists of academic performance tests, psychological tests, and a general medical check-up (Atma Jaya Catholic University of Indonesia, 2021).
There are three types of admission systems for public universities: 'Seleksi Nasional Masuk Perguruan Tinggi Negeri' (SNMPTN), 'Seleksi Bersama Masuk Perguruan Tinggi Negeri' (SBMPTN), and a local entrance examination organised by the university. The SNMPTN is a national-level admission examination administered by the Directorate General of Higher Education of the Ministry of Education and Culture, and it is applied in all Indonesian State Universities (College Entrance Test Institute, 2021). The SNMPTN mostly assesses the academic achievement of a prospective student. The SBMPTN is a joint admission examination of public universities administered by a selected committee by the Ministry of Education and Culture (College Entrance Test Institute, 2021). This admission consists of two tests: the scholastic potential to assess cognitive ability and the academic competency test to evaluate scientific knowledge and understanding. Lastly, the local entrance examination is organised by each university. Therefore, each university has the authority to design and execute its admission examination according to their respective characteristics. 
Generally, the admission process for all pharmacy schools in Indonesia is similar, except for the cut-off score to pass the entrance exam. Furthermore, the admission process for the professional pharmacist programme is managed by the university regardless of whether it is a private or public university. A prospective student should have obtained their undergraduate pharmacy degree and passed the entrance exam in order to enrol in the professional pharmacy programme (Padjajaran University, 2010; School of Pharmacy ITB, 2019; Universitas Pancasila, 2021).

\section{Pharmacy career opportunities}

Most undergraduate programmes in Indonesia are focused on general pharmacy, including pharmaceutical sciences and clinical pharmacy as a part of the curriculum. However, some schools like the Institut Teknologi Bandung (ITB) have clinical pharmacy and pharmaceutical science tracks at the undergraduate level. However, Institut IImu Kesehatan Medika Persada Bali only has a clinical pharmacy track (Institut IImu Kesehatan Medika Persada Bali, 2020; School of Pharmacy ITB, 2021) An undergraduate pharmacy programme consists of a clinical pharmacy and industrial pharmacy track (Association of Indonesian Pharmacy Higher Education, 2013). This track will determine the curriculum and internship opportunities.

Students from the industrial pharmacy track must undergo an internship in the pharmaceutical industry, and students from the clinical pharmacy track must be interns in a hospital. Students from both these programmes must also intern at a community pharmacy. Some universities also require students to do an internship at a public health centre (Gadjah Mada University, 2018; University of Indonesia, 2020). Students become competent in their chosen pharmacy major after completing a professional degree course and internship requirements.

A professional pharmacy graduate has broader career opportunities than a vocational or undergraduate programme graduate. They can pursue opportunities at a manager or supervisory level in pharmaceutical industries, hospitals, and community or public health centres. The vocational and undergraduate graduates can work as assistants to professional pharmacists (Government Regulation on Pharmaceutical Works, 2009). According to the 2009 Government Regulation No. 51, pharmacists can work in various work fields, including distribution facilities, pharmaceutical industries (medicines, raw materials, traditional medicines, and cosmetics), and pharmaceutical care facilities (pharmacy, hospital, public health care, clinic, drug store). Graduates from the Master's or Doctoral programme are more likely to become researchers or lecturers in educational institutions or as managers in the pharmaceutical industry.

\section{Challenges of pharmacy education in Indonesia}

The current demands for pharmacy graduates have led to an increase in the roles and responsibilities of pharmacists (Hermansyah et al., 2018). In 2019, there were 53,237 applicants for undergraduate pharmacy major programmes in government universities; however, all Indonesian universities have the combined capacity for only 1,589 admissions (around 3\% acceptance rate) (College Entrance Test Institute, 2021). Also, there is an imbalance in the number of undergraduate and professional pharmacy programmes. There are very limited professional programmes available to meet the growing demands of undergraduate students for a professional degree. Therefore, there is a strong need to increase the quantity and quality of pharmacy graduates in Indonesia (Indonesian Ministry of Education and Culture, 2020).

Concerted efforts are needed to respond to the increasing demand for high-quality pharmacy education in Indonesia. This requires maintaining high standards by equipping pharmacy students with knowledge and skills to meet the needs of increasing pharmacist roles. Since most pharmacy programmes are centred on Java Island, increasing access or starting pharmacy programmes in collaboration with other schools or universities outside Java Island is necessary (Indonesian Ministry of Education and Culture, 2020). The FIP and WHO collaborated to endorse a "needbased education," where the education system is built upon the country's needs. Considering the current situation, pharmacy education in Indonesia should respond to the increasing training and healthcare needs of the population (Anderson et al., 2008; Anderson et al., 2009). Because of the limited number of professional pharmacy programmes, many graduates cannot continue their studies to become professional pharmacists.

The Indonesian Ministry of Research Technology and Higher Education has a moratorium to limit undergraduate programmes. With increasing pharmaceutical needs in Indonesia, there is a significant demand for professionally trained pharmacists, and there is a need to lift this moratorium and encourage academic institutions to increase the training of pharmacists. Based on World Health Organisation Compendium, the necessary pharmacist ratio is about 1 per 10,000 inhabitants (World Health Organisation, 2014).

In 2016, there were 32,386 pharmacists in Indonesia, resulting in a pharmacist ratio of 1 per 7,700 Indonesian 
residents (Farmalkes, 2016). This ratio may be adequate for the pharmaceutical care needs of the country. However, pharmacy services beyond dispensing are underutilised in community settings. Also, community pharmacists have a low salary, and most pharmacists are hired for legal purposes, where healthcare providers need a pharmacist license to fulfil requirements to run healthcare facilities (Wibowo et al., 2015). The Ministry of Health Regulation No. 31 Year (2016) created another issue related to pharmacist availability as pharmacists could obtain up to three working licenses in three different pharmaceutical service facilities (Amendment to Health Minister Regulation Number 889/MENKES/PER/V/2011 Concerning Registration, Practice License, and Work Permit for Pharmaceutical Personnel, 2016). The Association of Indonesian Pharmacists, also known as Ikatan Apoteker Indonesia (IAI), has made a rule of "no pharmacist, no service" in order to increase pharmacist access in the community. A pharmacist can only extend their practice license if they attained a competency certificate every five years. Moreover, one of the requirements for certificate renewal is to have evidence of work in the facility where pharmaceutical services are needed. The IAI rule not only helps in improving pharmacist access and salaries but can also help in increasing pharmacist services in the community. Although the IAI rule was part of Government Regulation No. 15 2009, there is a greater need for enforcement and cooperation between the government and IAI to enhance community pharmacists' role in healthcare.

The APTFI has developed standards for the curriculum (Association of Indonesian Pharmacy Higher Education, 2013). These standards help maintain a consistent pharmacy curriculum across programmes in the country. However, more curricula should be devoted to early and advanced practice experiences like curricula in the United States to train students with pharmacy practice knowledge and skills (Accreditation Council for Pharmacy Education Accreditation, 2016). Additionally, there is a significant need to implement studentcentred learning methods and blended learning applications in the era of industry where digitalisation and automation are becoming trends in business models globally in order to improve health care (Chute \& French, 2019).

Blended learning incorporating face-to-face and online learning has become necessary in the current era, including pharmaceutical education (Margolis et al., 2017; Winanti et al., 2018). To become a competent pharmacist, students also need to learn about good communication skills and interprofessional education (Association of Indonesian Pharmacy Higher Education, 2013). These skills are essential to reduce conflicts while collaborating with other healthcare professionals
(Wallman et al., 2013). In addition, other core competencies such as ethics, responsibilities, and teamwork between healthcare professionals should be emphasised to improve collaboration (Brashers et al., 2020).

Another challenge in the clinical sector is that pharmaceutical service is considered to be a nonmedical service according to health minister regulations (Health Ministerial Regulation on Hospital Classification and Licensing, 2020). This regulation may also reduce the role of pharmacists in hospitals and affect pharmacists' self-confidence (Puspitasari et al., 2015). There are low expectations for clinical pharmacists from physicians and patients, and the limited government support can worsen the situation. Therefore, there is a greater need for interprofessional education to introduce pharmacist roles among other healthcare professionals in clinical settings. Also, there is a need for collective efforts from the Ministry of Health, physicians, administrators, and relevant pharmacy stakeholders, including the IAI, to increase the pharmacists' role in clinical settings.

\section{Conclusion}

The Indonesian pharmacy education programme consists of vocational, undergraduate, professional pharmacy, masters, and doctoral pharmacy programmes. The undergraduate programme is the primary requirement for applying to a professional pharmacy programme. The curriculum and learning outcomes of undergraduate and professional pharmacy programmes follow academic standards set by APTFI based on the seven-star pharmacist concept developed by the WHO. Undergraduate pharmacy programmes are focused on general pharmacy, which includes pharmaceutical sciences and clinical pharmacy, whereas the professional pharmacy programmes provide more pharmacy practice training and skills. The professional graduates have broader career opportunities compared to undergraduates as they are prepared for higher responsibilities. Although there have been significant improvements in pharmacy education, there are challenges related to government policies, stakeholder agreements, educational offerings, practice skills, competencies, and training. Therefore, there is a greater need for collective efforts from the government, educational systems, associations, and other stakeholders in order to advance the role of pharmacists in Indonesia. 


\section{References}

Accreditation Council for Pharmacy Education Accreditation. (2016). Accreditation Council for Pharmacy Education Accreditation Standards and Key Elements for The Professional Program in Pharmacy Leading to the Doctor of Pharmacy Degree. Accreditation Council for Pharmacy Education. https://www.acpeaccredit.org/pdf/Standards2016FINAL.pdf

Andayani, T.M., \& Satibi, S. (2016). Pharmacy Practice in Indonesia. In A.I. Fathelrahman, M.I.M. Ibrahim, \& A.I. Wertheimer (Eds.), Pharmacy Practice in Developing Countries (pp. 41-56). Academic Press. https://doi.org/10.1016/B978-0-12-801714-2.00003-4

Anderson, C., Bates, I., Beck, D., Brock, T., Futter, B., Mercer, H., Rouse, M., Wuliji, T., \& Yonemura, A. (2008). The WHO UNESCO FIP Pharmacy Education Taskforce: Enabling Concerted and Collective Global Action. American Journal of Pharmaceutical Education, 72(6), 127 https://doi.org/10.5688/aj7206127

Anderson, C., Bates, I., Beck, D., Brock, T. P., Futter, B., Mercer, H., Rouse, M., Whitmarsh, S., Wuliji, T., \& Yonemura, A. (2009). The WHO UNESCO FIP Pharmacy Education Taskforce. Human Resources for Health, 7, 45. https://doi.org/10.1186/1478-4491-7-45

Asia Pasific Observatory on Health Systems and Policies. (2017). The Republic of Indonesia Health System Review. Health Systems in Transition, 7(1)

Association of Indonesian Pharmacy Higher Education. (2013). Academic Script: Graduate Competencies Standard and Pharmacy Education Curriculum Standard for Undergraduate and Apothecary Study Program. Education Development Commission AIPHE

Atma Jaya Catholic University of Indonesia. (2021). Submit Online Application. https://admission.atmajaya.ac.id/

Azhar, S., Hassali, M.A., Ibrahim, M.I.M., Ahmad, M., Masood, I., \& Shafie, A.A. (2009). The role of pharmacists in developing countries: The current scenario in Pakistan. Human Resources for Health, 7, 54. PubMed. https://doi.org/10.1186/1478-4491-7-54

Basak, S.C., \& Sathyanarayana, D. (2010). Pharmacy education in India. American Journal of Pharmaceutical Education, 74(4), 68. PubMed.

https://doi.org/10.5688/aj740468

Brashers, V., Haizlip, J., \& Owen, J.A. (2020). The ASPIRE Model: Grounding the IPEC core competencies for interprofessional collaborative practice within a foundational framework. Journal of Interprofessional Care, 34(1), 128-132.

https://doi.org/10.1080/13561820.2019.1624513

Brawijaya University. (2019). Prodi yang Wajib Mengunggah Surat Keterangan Buta Warna pada Daftar Ulang SBMPTN/SNMPTN 2019 / SELMA UB. https://selma.ub.ac.id/prodi-yang-wajib-mengunggah-suratketerangan-buta-warna-pada-daftar-ulang-snmptn-2019/

Brawijaya University. (2020). Penerimaan Mahasiswa Baru Program Profesi Apoteker Semester Genap 2019/2020. https://selma.ub.ac.id/en/penerimaan-mahasiswa-baruprogram-profesi-apoteker-semester-genap-20192020/

Central Bureau of Statistics. (2010). Indonesian citizenship, ethnicity, religion, and everyday language: The results of the 2010 population census.

Chanakit, T., Low, B.Y., Wongpoowarak, P., Moolasarn, S., \& Anderson, C. (2014). A Survey of Pharmacy Education in Thailand. American Journal of Pharmaceutical Education, 78(9), 161. https://doi.org/10.5688/ajpe789161

Chute, C., \& French, T. (2019). Introducing Care 4.0: An Integrated Care Paradigm Built on Industry 4.0 Capabilities. International Journal of Environmental Research and Public Health, 16(12), 2247. PubMed.

https://doi.org/10.3390/ijerph16122247

College Entrance Test Institute. (2021). Website Resmi LTMPT. https://www.ltmpt.ac.id/

Embassy of the Republic of Indonesia Washington D.C. (2017). Facts \& Figures.

https://www.embassyofindonesia.org/index.php/basicfacts/

Farmalkes. (2016). Rapat Koordinasi Komite Farmasi Nasional 2016. Farmalkes.

https://farmalkes.kemkes.go.id/2016/08/rapat-koordinasikomite-farmasi-nasional/

Gadjah Mada University. (2018). Kurikulum - Program Studi Profesi Apoteker Fakultas Farmasi UGM.

https://apoteker.farmasi.ugm.ac.id/kurikulum/

Hermansyah, A., Sainsbury, E., \& Krass, I. (2018). Multiple policy approaches in improving community pharmacy practice: The case in Indonesia. BMC Health Services Research, 18(1), 449. https://doi.org/10.1186/s12913-0183258-8

Indonesian Ministry of Education and Culture. (2020). PDDikti-Pangkalan Data Pendidikan Tinggi. Retrieved November 12, 2019, from https://pddikti.kemdikbud.go.id/

Health Ministerial Regulation on Registration, Practice License, and Work Permit for Pharmaceutical Personnel, Pub. L. No. 889/MENKES/PER/V/2011, 1 (2011). https://peraturan.bpk.go.id/Home/Details/139675/permen kes-no-889menkesperv2011-tahun-2011

Amendment to Health Minister Regulation Number 889/MENKES/PER/V/2011 Concerning Registration, Practice License, and Work Permit for Pharmaceutical Personnel, Pub. L. No. 31, 1 (2016).

https://peraturan.bpk.go.id/Home/Details/113061/permen kes-no-31-tahun-2016 
Indonesian Ministry of Health. (2016). Core Curriculum of Vocational Pharmacy Education. Health Human Resources Development and Empowerment Agency.

http://bppsdmk.kemkes.go.id/pusdiksdmk/wpcontent/uploads/2017/10/KURIKULUM-INTI-D3-FARMASI2016.pdf

Health Ministerial Regulation on Hospital Classification and Licensing (2020).

https://peraturan.bpk.go.id/Home/Details/152506/permen kes-no-3-tahun-2020

Institut IImu Kesehatan Medika Persada Bali. (2020). Profil Program Studi Farmasi Klinis. http://www.unbi.ac.id/infoprodi/9/farmasi-klinis-s1.html

Mahendradhata, Y., Trisnantoro, L., Soewondo, P., Marthias, T., Harimurti, P., \& Prawira, J. (2017). The Republic of Indonesia Health System Review, Health Systems in Transition (W. Patcharanarumol \& K. Hort, Eds.; 1st ed., Vol. 7). WHO Regional Office for South-East Asia.

https://apps.who.int/iris/handle/10665/254716

Margolis, A.R., Porter, A.L., \& Pitterle, M.E. (2017). Best Practices for Use of Blended Learning. American Journal of Pharmaceutical Education, 81(3).

https://doi.org/10.5688/ajpe81349

Media, K. C. (2021, January 16). 20 Jurusan Kuliah IPA dengan Daya Saing Tinggi di SNMPTN 2020 Halaman 2. KOMPAS.com.

https://www.kompas.com/edu/read/2021/01/16/09000077 1/20-jurusan-kuliah-ipa-dengan-daya-saing-tinggi-disnmptn-2020

Organisation for Economic Co-Operation and Development (OECD). (2019). Education at A Glance.

https://www.oecd.org/education/education-at-aglance/EAG2019_CN_IDN.pdf

Padjajaran University. (2010). Persyaratan. Fakultas Farmasi Universitas Padjadjaran.

https://farmasi.unpad.ac.id/persyaratan/

Government Regulation on Pharmaceutical Works, Pub. L. No. 51, 1 (2009).

https://jdih.kemenkeu.go.id/fulltext/2009/51tahun2009pp. htm

Puspitasari, H. P., Aslani, P., \& Krass, I. (2015). Challenges in the management of chronic noncommunicable diseases by Indonesian community pharmacists. Pharmacy Practice, 13(3), 578. PubMed.

https://doi.org/10.18549/PharmPract.2015.03.578

Regulation of The President, The Republic of Indonesia No. 8. (2012).

School of Pharmacy ITB. (2019). Pharmacist Participant Requirements. https://usm.itb.ac.id/itb_versi1/programprofesi/program-apoteker\#program-profesi-persyaratanpeserta-apoteker
School of Pharmacy ITB. (2021). Struktur KurikulumSekolah Farmasi. https://fa.itb.ac.id/kurikulum-programdoktor/

Universitas Pancasila. (2021). Penerimaan Mahasiswa Baru Online Universitas Pancasila.

http://pmbonline.univpancasila.ac.id/apoteker/informasi/sy aratpeserta_apoteker.php

University of Indonesia. (2020). Kurikulum (Apt) Fakultas Farmasi Universitas Indonesia.

https://farmasi.ui.ac.id/program-studi/apoteker/kurikulum/

University of Indonesia. (2021). Persyaratan Pendaftaran Program Studi-Profesi Jalur SIMAK Periode 2018/2019 Semester 2. SIMAK-UI.

https://penerimaan.ui.ac.id/period/requirement/2282

Vo, T.-H., Bedouch, P., Nguyen, T.-H., Nguyen, T.-L.-H., Hoang, T.-K.-H., Calop, J., \& Allenet, B. (2013). Pharmacy education in Vietnam. American Journal of Pharmaceutical Education, 77(6), 114. PubMed.

https://doi.org/10.5688/ajpe776114

Wallman, A., Vaudan, C., \& Sporrong, S.K. (2013).

Communications training in pharmacy education, 1995-

2010. American Journal of Pharmaceutical Education, 77(2), 36. PubMed. https://doi.org/10.5688/ajpe77236

Wibowo, Y., Parsons, R., Sunderland, B., \& Hughes, J. (2015). Evaluation of community pharmacy-based services for type2 diabetes in an Indonesian setting: Pharmacist survey. International Journal of Clinical Pharmacy, 37(5), 873-882. https://doi.org/10.1007/s11096-015-0135-y

Wiedenmayer, K., Rob S. Summers, Clare A. Mackie, Andries G.S. Gous, Marthe Everard, \& Dick Tromp. (2006). Developing Pharmacy Practice: A Focus on Patient Care: Handbook. World Health Organization and International Pharmaceutical Federation.

https://apps.who.int/iris/handle/10665/69399

Winanti, F.L. Gaol, T.A. Napitupulu, H. Soeparno, \& A. Trisetyarso. (2018). Learning Framework in the Industrial Age 4.0 in Higher Education. 2018 Indonesian Association for Pattern Recognition International Conference (INAPR), 227-232. https://doi.org/10.1109/INAPR.2018.8627039

World Health Organization. (1997). The role of the pharmacist in the health care system: Preparing the future pharmacist: Curricular development: Report of a third WHO Consultative Group on the Role of the Pharmacist. World Health Organization.

https://apps.who.int/iris/bitstream/handle/10665/63817/ WHO_PHARM_97_599.pdf?sequence=1\&isAllowed=y

World Health Organization. (2014). World Health Statistics 2014-Indicator Compendium. World Health Organization. https://www.who.int/gho/publications/world_health_statis tics/whs2014_indicatorcompendium.pdf?ua $=1$

World Health Organization. (2020). Indonesia. https://www.who.int/countries/idn/en 